
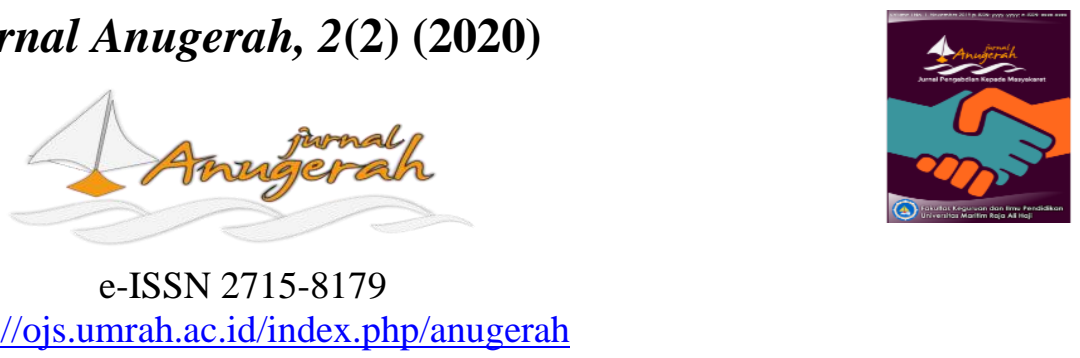

https://ojs.umrah.ac.id/index.php/anugerah

\title{
Pelatihan Mengembangkan Bahan Ajar Kimia Berbasis Literasi Sains Mengintegrasikan Konteks Kemaritiman
}

\author{
Inelda Yulita ${ }^{1}$, Trisna Amelia ${ }^{2 *}$ \\ ${ }^{1}$ Program Studi Pendidikan Kimia \\ ${ }^{2}$ Program Studi Pendidikan Biologi \\ Universitas Maritim Raja Ali Haji, Tanjungpinang, Kepulauan Riau, 29122, Indonesia \\ *e-mail korespondensi: trisna.amelia@umrah.ac.id
}

Pengiriman: 25 Oktober 2020; Diterima: 23 November 2020; Publikasi: 30 November 2020

DOI: https://doi.org/10.31629/anugerah.v2i2.2685

\begin{abstract}
Abstrak
Kemampuan literasi sains tidak hanya dibutuhkan oleh siswa, melainkan juga guru sebagai pengelola pembelajaran. Guru yang mampu mengembangkan bahan ajar berbasis literasi sains, akan mampu meningkatkan kemampuan literasi sains pada siswa. Oleh karena itu, penting bagi guru mata pelajaran kimia untuk dapat mengembangkan bahan ajar berbasis literasi. Program pelatihan ini bertujuan untuk membantu guru mengembangkan bahan ajar kimia yang berbasis literasi sains. Guru dilatih untuk mengintegrasikan konteks kemaritiman kedalam salah satu materi kimia. Program ini diterapkan kepada 3 orang guru kimia di SMA Negeri 4 Tanjungpinang. Metode pelatihan menggunakan model siklus Plan, Do, Check, dan Act. Kegiatan yang dilakukan selama 4 minggu. Hasil dari pelatihan adalah dihasilkannya bahan ajar berupa modul kimia materi asam basa kelas XI dengan konteks lingkungan hidup gonggong.
\end{abstract}

Kata kunci: bahan ajar kimia; literasi sains; pelatihan

\begin{abstract}
Science literacy skills are not only needed by students, but also teachers as learning managers. Teachers who are able to develop scientific literacy-based teaching materials will be able to improve student scientific literacy. Therefore, it is important for chemistry subject teachers to be able to develop literacy-based teaching materials. This training program aims to help teachers developing chemistry teaching materials based on scientific literacy. Three chemistry teachers of SMA Negeri 4 Tanjungpinang were trained to integrate the maritime context into one of the chemistry subject lesson. The training method used the Plan, Do, Check, and Act cycle model. Activities were carried out for 4 weeks. The result of the training is teaching materials in the form of acid-base chemical modules for class XI with the environmental context of Gonggong environment.
\end{abstract}

Keywords: chemical teaching materials; scientific literacy; training

\section{Pendahuluan}

Literasi sains adalah kemampuan peserta didik dalam memahami sains, mengkomunikasikannya dan mengambil keputusan terhadap situasi yang terjadi dalam kehidupan (Toharudin, 2011). Melalui literasi sains logika berpikir peserta didik menjadi sistematis terarah dalam memandang alam lingkungannya, mengidentifikasi masalah yang ada serta pemecahannya. Maka dari itu, penting untuk mengembangkan bahan ajar oleh para guru, khususnya guru kimia. 


\section{JURNAL ANUGERAH, November 2020; Vol 2(2): 51 - 65}

\section{e-ISSN 2715-8179}

Pembelajaran sains sesungguhnya mempunyai kekuatan untuk membangun kemampuan berpikir peserta didik. Kemampuan merumuskan pertanyaan, berpikir analitis, sintesis, kritis dan pemecahan masalah dapat dikembangkan melalui kegiatan inkuiri sains. Sejalan dengan pengertian Programme for International Student Assessment (PISA) mengenai literasi sains (OEDC dalam (Toharudin, 2011)), kerangka untuk asesmen PISA dapat dilihat pada : 1) Konteks, situasi dalam kehidupan sehari-hari yang melibatkan sains dan teknologi, 2) Kompetensi, yaitu mengidentifikasi isu-isu ilmiah, menjelaskan fenomena secara ilmiah, dan menggunakan bukti ilmiah untuk membuat dan mengkomunikasikan keputusan, 3) Pengetahuan, yaitu pengetahuan tentang alam (konsep dasar) dan pengetahuan tentang sains, 4) Sikap, merupakan respon terhadap isu sains: minat, dukungan terhadap inkuiri ilmiah, dan tanggung jawab.

Dalam penilaian tingkat literasi sains peserta didik, ada dua hal yang perlu diperhatikan, yaitu : pertama, penilaian literasi sains peserta didik tidak ditujukan untuk membedakan seseorang literat atau tidak dan kedua, pencapaian literasi sains merupakan proses yang kontinu dan terus menerus berkembang sepanjang hidup manusia (Schwartz et al., 2004). Jadi, penilaian literasi sains selama pembelajaran di sekolah hanya melihat adanya "benih-benih literasi" dalam diri peserta didik, bukan menilai secara mutlak tingkat literasi sains dan teknologi peserta didik (Shwartz et al., 2006).

Berbagai hasil penelitian menjelaskan bahwa pendidikan dewasa ini harus membekali peserta didik dengan keterampilan untuk menghadapi tantangan global dan kebutuhan lingkungan kerja (Snow \& Dibner, 2016). Sehingga, peserta didik tidak hanya membutuhkan pengetahuan dan keterampilan motorik saja namun perlu dibekali dengan kecakapan hidup (life skills) yang merupakan sarana bagi tumbuhnya keterampilan berkomunikasi dan keterampilan menyelesaikan masalah-masalah aktual dalam kehidupan bermasyarakat. Untuk dapat melakukan hal tersebut, diperlukan sumber daya manusia yang literate atau melek sains. Kenyataannya, hasil tes PISA menunjukkan bahwa pelajar sekolah menengah di Indonesia memiliki tingkat literasi yang tergolong rendah. Berbagai penelitian yang dilakukan secara umum di Indonesia, menunjukkan bahwa kemampuan literasi sains peserta didik di Indonesia masih kurang sekali terutama pada kemampuan berpikir dan bekerja ilmiah (Diana et al., 2015).

Kemampuan literasi sains tidak hanya dibutuhkan oleh siswa, melainkan juga guru sebagai pengelola pembelajaran. Guru yang mampu mengembangkan bahan ajar berbasis literasi sains, akan mampu meningkatkan kemampuan literasi sains pada siswa. Dijelaskan Grant dan Dianne (2011) bahwa ada empat cara yang dapat dilakukan pendidik untuk meningkatkan literasi sains di kelas yaitu; mengidentifikasi topik ilmu yang menarik dan mengintegrasikan ke dalam ajaran topik dalam kurikulum, melibatkan peserta didik dalam membaca hasil penelitian, ajari peserta didik untuk membaca seperti para ilmuwan dan membimbing pelajar untuk mengevaluasi data. Untuk dapat melakukan empat hal tersebut, penting bagi guru mata pelajaran kimia memiliki kemampuan mengembangkan pembelajaran berbasis literasi sains.

Situasi yang terjadi pada sekolah mitra (SMA Negeri 4 Tanjungpinang) dalam pembelajaran kimia, belum dilakukan secara maksimal pembelajaran dengan tujuan menumbuhkembangkan literasi sains. Pembelajaran masih menekankan pada produk sains (pengetahuan tekstual), belum ada proses menghubungkan dengan fenomena ilmiah yang ada disekitar, apalagi mengarah kepada terbentuknya kecakapan hidup berkaitan dengan lingkungan kontekstual. Pencapaian kemampuan literasi sains pada siswa perlu direncanakan dengan baik oleh guru sebagai pengelola pembelajaran.

Sebagaimana dijelaskan Uno (2008) untuk meningkatkan kualitas pembelajaran, harus dimulai dengan upaya melakukan perencanaan pembelajaran. Demikian juga halnya dengan pembelajaran literasi sains untuk meningkatkan literasi sains siswa, maka guru harus memiliki kemampuan merencanakan proses pembelajaran berbasis literasi sains. Berkaitan dengan upaya meningkatkan kemampuan guru dalam mendesain pembelajaran berbasis literasi sains dengan muatan kemaritiman telah dilakukan oleh tim pada tahun 2019 (Amelia \& Yulita, 2019). Sebagai output dari kegiatan tersebut, guru kimia di SMA Negeri 4 Tanjungpinang sudah mampu mendesain pembelajaran berbasis literasi sains melalui penerapan tahapan 
pendekatan pembelajaran Science and technology literacy (STL). Namun, untuk lebih mengembangkan kemampuan guru dalam menerapkan pembelajaran berbasis literasi sains, tentu perlu kegiatan pelatihan yang berkelanjutan, yaitu melalui pelatihan pengembangan bahan ajar berbasis literasi sains.

Menindaklanjuti perlunya keberlanjutan upaya meningkatkan kemampuan guru merencanakan pembelajaran berbasis literasi sains, maka dilakukan kegiatan program pelatihan untuk membantu guru mengembangkan bahan ajar kimia yang berbasis literasi sains. Pada program ini, guru dilatih untuk mengintegrasikan konteks kemaritiman ke dalam salah satu materi kimia. Kegiatan pengabdian mengenai pelatihan pengembangan bahan ajar, sangat layak dilakukan, sebagaimana penelitian terdahulu mengenai analisis literasi sains siswa terhadap konteks teknologi printer inkjet (Yulita, 2016), konteks kemaritiman (Yulita, 2018), perspektif saintis dan prekonsepsi peserta didik terhadap konten kimia dengan konteks teknologi (Yulita, 2016a; 2016b), dan desain bahan ajar yang berbasis literasi sains (Yulita, 2017). Oleh karena itu, penting untuk dilakukan pelatihan pengembangan bahan ajar kimia berbasis literasi sains menggunakan konteks kemaritiman oleh guru kimia.

\section{Metode}

Pelaksanaan program ini mengadopsi model siklus Deming (PDCA), yang terdiri dari 4 tahapan yaitu Plan, Do, Check, Act (Rencanakan, Kerjakan, Cek, Tindak lanjuti) (Riyantini, 2017). Metode ini diimplementasikan dalam kegiatan berikut.

1. Tahap Plan, mengidentifikasi dan menganalisis masalah.

2. Tahap Do, mengembangkan dan menemukan solusi terhadap masalah yang teridentifikasi.

3. Tahap Check, mengukur seberapa efektif pengujian solusi sebelumnya dan menganalisis apakah langkah tersebut dapat ditingkatkan.

4. Tahap Act, mengimplementasikan solusi yang telah ditingkatkan secara menyeluruh.

Tiap tahapan PDCA diimplementasikan dalam kegiatan sebagai berikut.

1. Pelatihan (Plan)

Pelatihan dilakukan melalui penyampaian konsep pengembangan bahan ajar berbasis literasi sains dengan mengangkat konteks kemaritiman. Kegiatan ini dilakukan secara daring dalam bentuk webinar. Narasumber dalam tahapan ini memberdayakan pakar dari luar institusi dan mengundang lebih banyak peserta, sehingga berdampak lebih luas.

2. Workshop (Do)

Workshop yang dilakukan dalam dua kali pertemuan di sekolah mitra (SMA Negeri 4 Tanjungpinang). Kegiatan ini dilakukan dengan memberikan arahan dan kerangka dasar pengembangan bahan ajar berbasis literasi sains kepada guru. Pendampingan dilakukan secara intensif selama tatap muka dan juga melalui media komunikasi daring.

3. Pembahasan dan refleksi kegiatan (Check dan Act)

Dari kegiatan yang dilakukan, output yang diharapkan adalah tercapai peningkatan kemampuan guru dalam mengembangkan bahan ajar berbasis literasi sains dengan muatan konteks kemaritiman. Melalui kegiatan refleksi maka didiskusikan dan ditelaah kesesuaian bahan ajar yang sudah dikembangkan oleh guru di dalam tim.

Kegiatan pelatihan ini diikuti oleh 7 orang peserta, yang merupakan guru mata pelajaran biologi dan kimia di SMA Negeri 4 Tanjungpinang. Khusus guru kimia, terdapat 3 orang guru dari keseluruhannya. Dari kegiatan yang dilakukan, keberhasilan kegiatan diukur dari capaian peningkatan kemampuan guru dalam mengembangkan bahan ajar berbasis literasi sains dengan muatan konteks kemaritiman. Output ini diukur 
JURNAL ANUGERAH, November 2020; Vol 2(2): 51 - 65

e-ISSN 2715-8179

menggunakan lembar observasi terhadap aktivitas pengembangan bahan ajar selama proses pelatihan serta studi dokumentasi terhadap bahan ajar yang dibuat oleh guru sebelum dan sesudah pelatihan. Teknik penyebaran angket juga dilakukan untuk memperoleh data dukung persepsi guru terhadap pentingnya integrasi literasi sains dan konteks kemaritiman dalam pembelajaran kimia.

\section{Hasil dan Pembahasan}

Pelaksanaan workshop dengan tema "Pengembangan Bahan Ajar Biologi Dan Kimia Bermuatan Kemaritiman Untuk Membangun Literasi Sains Siswa" dibagi menjadi 4 tahapan, yaitu, Plan, Do, Check, dan Act yang berlangsung selama 4 minggu. Pada setiap kegiatan semua guru terlibat aktif selama pelatihan, mulai dari merencanakan hingga melakukan refleksi di akhir kegiatan.

Pada pelatihan ini peserta diperkenalkan dengan konsep literasi sains. Literasi sains adalah kemampuan dalam mengkomunikasikan sains terhadap konteks-konteks yang ada dalam kehidupan, sehingga dapat membentuk sikap dan membuat keputusan (Toharudin, 2011). Dengan kemampuan ini diharapkan bahan ajar yang dihasilkan akan mampu membuat siswa meleks sains, sebagaimana data Programme for International Student Assessment (PISA) yang masih menunjukkan tingkat literasi peserta didik Indonesia masih berada di level rendah. Data PISA 2018 menunjukkan peserta didik Indonesia berada pada urutan 74 dari 79 negara (Schleicher, 2019). Dengan demikian, pengembangan bahan ajar kimia dapat menjadi solusi untuk meningkatkan literasi sains peserta didik.

Dalam pelatihan, guru diberikan kebebasan untuk menginterpretasikan konten kimia SMA ke dalam konteks kemaritiman, dengan memanfaatkan berbagai sumber, baik buku, jurnal, maupun internet. Kemampuan guru sudah cukup memadai, karena sudah mampu menerapkan konteks kemaritiman dan konten kimia SMA, hal ini sejalan dengan penelitian (Asikin \& Yulita, 2019) yang menyatakan pandangan literasi sains calon guru sudah juga cukup memadai. Guru menghubungkan materi kimia asam basa kelas XI dengan konteks lingkungan hidup Gonggong. Hal ini diterapkan dengan penguatan bahwa gonggong merupakan potensi daerah Kepulauan Riau.

Hasil kegiatan akan dibagi ke dalam 4 tahap, yang digambarkan sebagai berikut:

1. Tahap Plan

Pada tahap ini, tim pengabdian bersama guru-guru membuat perencanaan mengenai kegiatan workshop. Pada tahap ini juga ditentukan tujuan yang akan capai setelah selesai workshop. Adapun tujuan kegiatan pelatihan ini adalah:

a. Penyusunan indikator dan tujuan pembelajaran berbasis literasi sains

b. Analisis dan pemroduksian wacana teks.

c. Pengembangkan kisi-kisi literasi sains

d. Evaluasi

Adapun permasalahan yang ada digali dari guru-guru kimia melalui wawancara dan menghasilkan beberapa poin, yaitu: a) Guru belum pernah mengembangkan bahan ajar yang berbasis literasi sains, dan b) Guru tidak mengenal konteks kemaritiman secara mendalam. Untuk teknis pelaksanaan, kegiatan plan dilakukan menjadi 2 bagian, pertama persiapan administratif, kedua persiapan workshop. Pertama, persiapan administratif, tim pengabdian bersama-sama guru menentukan jadwal yang telah disesuaikan dengan jadwal mengajar, agar pelaksanaan workshop tidak mengganggu kegiatan sekolah. Selanjutnya pengurusan surat izin dari kepala sekolah SMAN 4 Tanjungpinang, yang diwakili oleh waka kurikulum.

Bagian persiapan workshop, tim pengabdian bersama guru menentukan rundown kegiatan, mulai dari penentuan durasi waktu yang dibutuhkan, hingga teknis pelaksanan workshop. Dari Tahap plan ini didapatkan hasil, sebagai berikut: 
a. Tanggal 24 Agustus 2020 dilaksanakan pembekalan melalui webinar yang mendatangkan pakar literasi dan pakar kemaritiman. Kegiatan ini dilakukan agar membantu guru mendapatkan pemahaman konsep mengenai literasi sains dan konteks kemaritiman langsung dari pakarnya. Kegiatan webinar dibuka juga untuk guru sains yang lain diluar guru-guru kimia SMAN 4 Tanjungpinang, mengingat kebermanfaatan dari pemaparan konsep dari ahli, yang layak dimanfaatkan oleh guru-guru.

b. Tanggal 1 hingga 22 September dilaksanakan pelatihan tatap muka, dengan mematuhi protokol kesehatan yang ketat. Kegiatan berlangsung satu kali dalam satu minggu. Satu kali pelatihan tatap muka, enam hari berikutnya penugasan terstruktur. Adapun kegiatan workshop meliputi; penentuan konteks kemaritiman yang tepat dan penentuan konten materi kimia yang sesuai dengan konteks yang dipilih. Kemudian, mengembangkannya dalam bentuk bahan ajar kimia. Sebagaimana yang ditampilkan pada tabel 1 .

Tabel 1

Jadwal Pelatihan Pengembangan Bahan Ajar

Tanggal Kegiatan

\begin{tabular}{ll}
\hline 24 Agustus 2020 & Pembekalan melalui webinar bersama pakar literasi sains dan pakar \\
& kemaritiman \\
$1,8,15$, dan 22 September 2020 & Pelatihan tatap muka \\
$2-7,9-14$, dan $16-21$ September 2020 & Penugasan terstruktur
\end{tabular}

2. Tahap Do

Pada tahap do, dilaksanakan kegiatan-kegiatan yang telah direncanakan pada tahap plan. Kegiatan pertema yang dilakukan adalah pembekalan mengenai pengetahuan tentang literasi sains dan konteks kemaritiman dari pemateri-pemateri ahli melalui webinar. Pemateri pertama berasal dari Universitas Pendidikan Indonesia sebagai pakar literasi sains, dan pemateri kedua berasal dari Universitas Maritim Raja Ali Haji sebagai pakar kemaritiman.

Pada materi tentang literasi sains di jabarkan tentang pengenalan tentang literasi sains, pentingnya pengembangan bahan ajar berbasis literasi sains, kemudian tahapan pengembangan bahan ajarnya. Pada pembukaan materi disampaikan kondiri terbaru mengenai asesmen siswa Indonesia dalam skala Internasional, yaitu melalui hasil PISA terbaru tahun 2018. Data PISA 2018 menunjukkan peserta didik Indonesia berada pada urutan 74 dari 79 negara (Schleicher, 2019). Terdapat empat dimensi literasi sains yang menjadi kerangka dasar untuk mengembangkan bahan ajar. Keterhubungan empat dimensi literasi sains tersebut digambarkan sebagai berikut; 
JURNAL ANUGERAH, November 2020; Vol 2(2): 51 - 65

e-ISSN 2715-8179

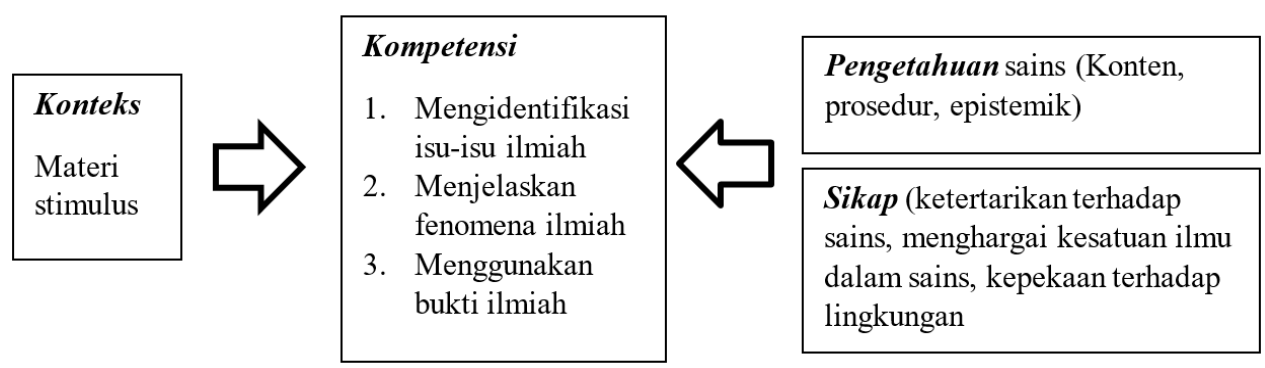

Gambar 1. Bagan hubungan aspek-aspek literasi sains (OECD, 2020)

Selanjutnya pada materi kemaritiman disampaikan mengenai perbedaan kemaritiman dan kelautan, dimana ranah pembahasan kemaritiman jauh lebih luas dibandingkan kelautan. Kelautan didefinisikan sebagai perihal yang berhubungan dengan laut dari bentuk/segifisik, sedangkan kemaritiman berkenaan dengan laut, berhubungan dengan pelayaran dan perdagangan di laut tidak sekedar fisikal. Lalu juga disampaikan irisan dengan mata pelajaran kimia dan biologi. Hal ini membantu memberikan gambaran kepada guru-guru sains, mengenai keterkaitan konten sains dengan konteks kemaritiman.

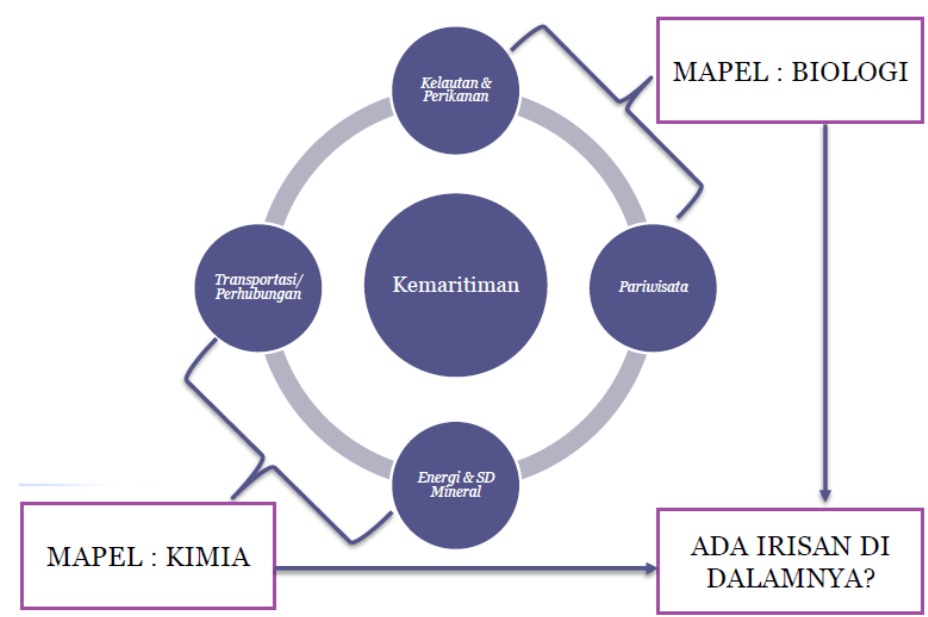

Gambar 2. Keterkaitan mata pelajaran sains dengan konteks kemaritiman

Berikutnya, setelah melakukan webinar sebagai pembekalan para guru kimia dalam mengembangkan bahan ajar, maka kegiatan berikutnya dilanjutkan dengan pelatihan pengembangannya. Langkah pertama yang dilakukan adalah menemukan keterhubungan antara konten kimia dan konteks kemaritiman, sebagaimana halnya penelitian (Yulita, 2018) yang menghubungkan konteks air laut dalam konten hakikat ilmu kimia dan juga penelitian (Asikin \& Yulita, 2019) yang menghubungkan konten materi larutan kimia dengan konteks pencemaran laut. Berikut gambaran pengembangan bahan ajar yang telah dilakukan oleh guru kimia SMAN 4 Tanjungpinang pada tahap menghubungkan konten kimia dan konteks kemaritiman. 
Tabel 2

Hasil Pengembangan Bahan Ajar oleh Guru pada Tahap Menemukan Keterhubungan Konten dan Konteks

\begin{tabular}{|c|c|c|}
\hline Konten & Konteks & Keterhubungan konten dan konteks \\
\hline $\begin{array}{l}\text { Indikator asam } \\
\text { basa }\end{array}$ & $\begin{array}{l}\text { Lingkungan hidup } \\
\text { gonggong }\end{array}$ & $\begin{array}{l}\text { Setiap makhluk hidup memiliki lingkungan dengan kondisi asam atau basa } \\
\text { tertentu. Ada makhluk hidup yang sensitif dengan tingkat keasaman air. } \\
\text { Gonggong tidak bisa hidup di laut yang lebih asam atau lebih basa. } \\
\text { Gonggong cenderung hidup di } p \mathrm{H} \text { netral. }\end{array}$ \\
\hline $\begin{array}{l}\text { Pembuktian } \\
p \mathrm{H}\end{array}$ & $\begin{array}{l}\text { Perbedaan } p \mathrm{H} \text { air } \\
\text { laut }\end{array}$ & $\begin{array}{l}\text { Air laut memiliki } p \mathrm{H} \text { tertentu. Tidak semua bagian air laut memiliki } p \mathrm{H} \\
\text { yang sama. Laut bagian tepi, tengah, permukaan atau dalam. Dan kondisi air }\end{array}$ \\
\hline & & laut yang tercemar akan dibuktikan apakah mempengaruhi $p \mathrm{H}$ air laut. \\
\hline
\end{tabular}

Setelah menemukan keterhubungan antara konten dengan konteks kemaritiman, maka, guru merumuskan tujuan pembelajaran yang sesuai. Adapun tujuan pembelajaran diturunkan dari KD kurikulum 2013 revisi, yaitu KD. 3.10 Menjelaskan konsep asam dan basa serta kekuatannya dan kesetimbangan pengionannya dalam larutan. Tujuan pembelajaran yang dirumuskan adalah: Peserta didik mampu menjelaskan tentang pengertian dan indikator asam basa melalui konteks gonggong yang hidup di perairan Kepulauan Riau, dengan tepat. Tujuan pembelajaran ini dirancang mengikuti konsep ABCD (Audience, Behavior, Condition, Degree). Pada tujuan yang dirumuskan sudah memenuhi persyaratan sebuah tujuan pembelajaran yang disayaratkan oleh Uno (2008).

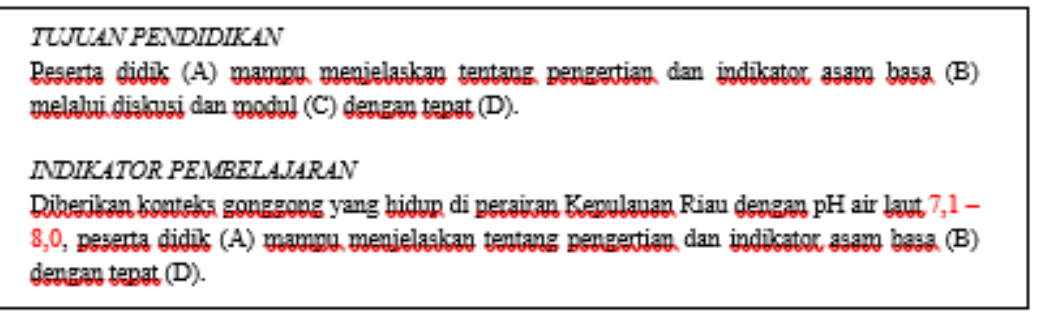

Gambar 3. Penetapan Tujuan dan Indikator Pembelajaran

Audience menunjukkan pelaku yang menjadi kelompok sasaran pembelajaran, yaitu peserta didik. Behavior menunjukkan perilaku yang dapat diamati sebagai hasil belajar, yaitu mampu menjelaskan tentang pengertian dan indikator asam basa. Condition menunjukkan perilaku yang dapat diamati sebagai hasil belajar, yaitu melalui konteks gonggong yang hidup di perairan Kepulauan Riau. Sedangkan Degree menunjukkan tingkatan keberhasilan yang ditargetkan, yaitu dengan tepat. Bentuk ringkasnya dapat dituliskan sebagai berikut: Peserta didik (A) mampu menjelaskan tentang pengertian dan indikator asam basa (B) melalui konteks gonggong yang hidup di perairan Kepulauan Riau (C) dengan tepat (D).

\section{Tahap Check}

Pada tahap ini diperiksa mengenai kondisi awal kemampuan literasi guru melakukan wawancara dan telaah dokumen, didapatkan hasil bahwa guru belum pernah mengembangkan bahan ajar yang berbasis literasi sains, guru juga belum mengenal secara mendalam konsep literasi sains, dan guru baru mengenal 
JURNAL ANUGERAH, November 2020; Vol 2(2): 51 - 65 e-ISSN 2715-8179

konsep literasi sains melalui pelatihan ini, serta guru belum pernah menggunakan konteks kemaritiman dalam menyampaikan materi kimia. Dari hasil yang didapatkan, maka tim pengembang menyimpulkan bahwa guru harus mendapatkan pemahaman tentang literasi sains terlebih dahulu, sebelum mengembangkan bahan ajar.

Strategi pertama yang dilakukan adalah memastikan semua guru mengikuti pemaparan materi dari pakar literasi sains dan pakar kemaritiman. Bahan presentasi dan kesempatan bertanya diberikan khusus, agar dapat menjadi sumber inspirasi dan membantu meluruskan kebingungan yang dialami sebelumnya. Strategi yang kedua adalah melakukan refleksi setelah mengikuti workshop. Dengan membentuk diskusi kelompok kecil antara tim pengabdian dan guru-guru kimia SMAN 4 Tanjungpinang, dilakukan pengecekan kondisi guru setelah mengikuti workshop. Didapatkan hasil bahwa guru-guru sudah mulai memahami konsep literasi sains dan sudah mendapat gambaran konteks kemaritiman. Kesempatan bertanya diberikan kepada guru hingga semua kebingungan yang menghambat proses pengembangan bahan ajar nantinya. Refleksi dihentikan setelah semua guru merasa nyaman dengan konsep yang mereka akan kembangkan. Dan terakhir, strategi ketiga yang dilakukan adalah tim pengembangan membantu guru dengan menyediakan kisi-kisi literasi sains. Kisi-kisi ini berupa panduan yang dapat diikuti guru agar memudahkan saat pengembangan bahan ajar.

\section{Tahap Act}

Setelah melakukan tahap check, guru melanjutkan proses pengembangan bahan ajar yang dipandu oleh tim pengabdian. Selama 3 kali pelatihan tatap muka, guru ditempa untuk mengembangkan bahan ajar kimia. Hasil pengembangan didapatkan bahan ajar berupa modul kimia dengan konteks lingkungan hidup gonggong pada materi asam basa. Pengembangan bahan ajar mengikuti kisi-kisi literasi yang telah dirancang oleh tim pengabdian, yang memuat 4 aspek literasi, yaitu: konteks sains, pengetahuan, kompetensi, dan sikap.

Aspek konteks sains merupakan isu-isu personal, lokal/nasional dan global, baik yang telah lalu maupun yang sedang terjadi, yang menutut pemahaman terhadap sains dan teknologi. Aspek pengetahuan menunjukkan pemahaman terhadap fakta, konsep, teori utama yang mendasari pengetahuan sains. Pengetahuan itu meliputi pengetahuan tentang alam dan artefak (produk) teknologi (pengetahuan konten), pengetahuan bagaimana gagasan tersebut dihasilkan (pengetahuan prosedural), dan pemahaman rasional bagi prosedur-prosedur tersebut dan justifikasi terhadap penggunaannya (pengetahuan epistemik). Aspek kompetensi menunjukkan kemampuan untuk memberikan eksplanasi terhadap fenomena secara ilmiah, mengevaluasi dan mendesain penyelidikan ilmiah, menafsirkan data dan bukti secara ilmiah. Selanjutnya aspek sikap menunjukkan ketertarikan atau kepedulian peserta didik terhadap sains, menghargai kesatuan ilmu dalam sains, dan kepekaan terhadap lingkungan.

Pada modul yang dikembangkan, guru mengangkat konteks gonggong yang merupakan komoditas pangan khas Tanjungpinang yang memiliki habitat dengan kadar $p \mathrm{H}$ yang unik. Guru menyajikan teks mengenai gonggong dan karakteristik habitat serta perannya untuk menstimulus peserta didik mempelajari konsep asam basa. Pada bahan ajar lazimnya tidak ditemukan stimulus dengan konteks yang memadai dan benar-benar kontekstual dengan lingkungan kemaritiman sebagaimana yang dikembangkan oleh tim guru dengan pendampingan fasilitator kegiatan.

Aspek pengetahuan pada dasarnya merupakan bagian dari struktur keilmuan kimia, sehingga untuk menyajikannya guru dapat menggunakan referensi berupa buku paket yang sudah ada. Sehingga, untuk menyajikan aspek pengetahuan relatif lebih mudah dibandingkan aspek lainnya. 


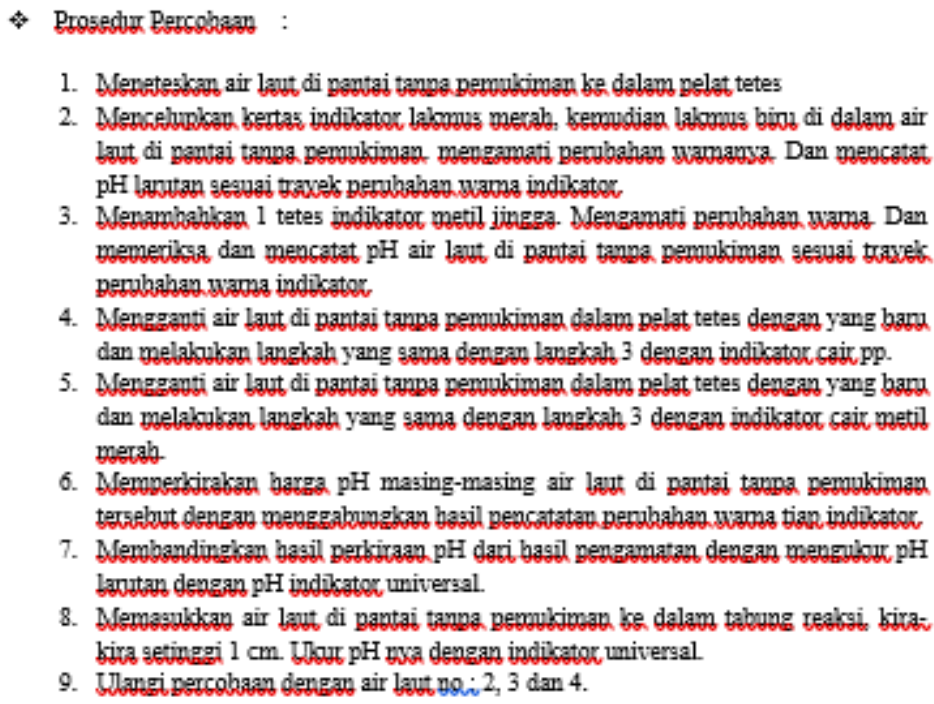

3. Nenambahkan 1 tetes indikator metil jingeg. Nengamati peruhahan wama Dam memerika dan mencatat $\mathrm{pH}$ air laut di pantai tampa pemulkman sesuai taxek penubahan wama indikator.

4. Nengganti air laut di pantai tanpa peryukiman dalam pelat tetes dengan yang ban dan melakukan langkah yang gama dengan langkah 3 dengan indikator cair.pp.

5. Nengganti air laut di pantai tanpa permukiman dalam pelat tetes dengan yang ban dan melabukan langksh yang gama dengan langkah 3 dengan indikator gair metil merah.

6. Nemperkirakan harga $\mathrm{pH}$ masing-masing air laut di pantai tanpa perwukjman tersebut dengan menggabungkan hasil pencatatan perubahay wama tian indikator.

7. Nembandingkan hasil perkiraan $\mathrm{pH}$ dari hagil pengamatan dengan menguku $\mathrm{pH}$ lastan dengan $\mathrm{pH}$ indisator, universal.

8. Nemasukksy air laut di pantai tanpa pemukiman ke dalam tabung reaksi. kirakira getinggi $1 \mathrm{~cm}$. Uhar $\mathrm{pH}$ nXa dengan indikator universal

9. Jlangi percobaan dengan air laut ng $i 2,3$ dan 4 .

Gambar 4. Aspek Kompetensi pada Modul

Aspek sains berikutnya meliputi kompetensi sains dan sikap sains. Kompetensi sains dapat meliputi kemampuan menjelaskan fenomena ilmiah, kemampuan menginterpretasikan data ilmiah, kemampuan menjelaskan isu-isu ilmiah serta kemampuan menggunakan bukti ilmiah untuk menjelaskan suatu fenomena (Amelia et al, 2020).

\section{MARI ME-REFLEKSI \\ Coba kamu jawab pertanyaan berikut dan diskusikan dengan teman sebangkumu! \\ - Mengapa gonggong hanya hidup di laut Kepulauan Riau? \\ - Apakah ada pengaruh tingkat keasaman air laut? Jelaskan! \\ - Ielaskan cara mengendalikan pH air laut agar habitat}

\section{Gambar 5. Aspek Sikap pada Modul}

Bahan ajar yang dihasilkan telah memenuhi semua aspek literasi sains, dan telah diselesaikan untuk satu konsep materi kimia. Berikut gambaran hasil pengembangan bahan ajar kimia oleh guru kimia SMAN 4 Tanjungpinang, yaitu :

Tabel 3

Hasil Pengembangan Bahan Ajar Kimia Berbasis Literasi Sains dengan Konteks Kemaritiman

Aspek Hasil pengembangan

literasi Sains

Konteks
Lingkungan hidup gonggong antara $p \mathrm{H} \mathrm{7,1-8}$
Posisi pada bahan

ajar

di awal


JURNAL ANUGERAH, November 2020; Vol 2(2): 51 - 65

e-ISSN 2715-8179

\begin{tabular}{|c|c|c|}
\hline Pengetahuan & $\begin{array}{l}\text { - Pengertian asam basa menurut Arhenius, Bronsted Lowry, dan Lewis. } \\
\text { - Indikator asam basa menggunakan kertas lakmus, larutan indikator, } \\
\text { indikator alami, indikator universal, dan } \mathrm{pH} \text { meter. }\end{array}$ & $\begin{array}{l}\text { Di batang } \\
\text { bahan ajar }\end{array}$ \\
\hline Kompetensi & $\begin{array}{l}\text { - Setiap makhluk hidup memiliki lingkungan dengan kondisi asam atau } \\
\text { basa tertentu. Ada makhluk hidup yang sensitif dengan tingkat } \\
\text { keasaman air. Gonggong tidak bisa hidup di laut yang lebih asam atau } \\
\text { lebih basa. Gonggong cenderung hidup di } p \mathrm{H} \text { netral. } \\
\text { - } \text { Air laut memiliki } p \mathrm{H} \text { tertentu. Tidak semua bagian air laut memiliki } \\
p \mathrm{H} \text { yang sama. Laut bagian tepi, tengah, permukaan atau dalam. Dan } \\
\text { kondisi air laut yang tercemar akan dibuktikan apakah mempengaruhi } \\
p \mathrm{H} \text { air laut. }\end{array}$ & $\begin{array}{l}\text { Di batang } \\
\text { bahan ajar }\end{array}$ \\
\hline Sikap & $\begin{array}{l}\text { - Mengapa gonggong hanya hidup di laut Kepulauan Riau? Apakah ada } \\
\text { pengaruh tingkat keasaman air laut? Jelaskan! } \\
\text { - Jelaskan cara mengendalikan } p \mathrm{H} \text { air laut agar habitat gonggong tetap } \\
\text { terjaga? }\end{array}$ & Di akhir bahan ajar \\
\hline
\end{tabular}

Dari proses pengembangan bahan ajar oleh guru-guru Kimia di SMA Negeri 4 Tanjungpinang, diperoleh data peningkatan kemampuan guru dalam menyusun bahan ajar yang sesuai dengan kerangka literasi sains dan bermuatan konteks kemaritiman. Berikut adalah data peningkatan kemampuan guru kimia.

Tabel 4

Peningkatan Keterpenuhan Aspek Bahan Ajar Berbasis Literasi Sains Sebelum dan Sesudah Kegiatan Pelatihan

\begin{tabular}{|c|c|c|c|c|}
\hline \multirow[t]{2}{*}{ No } & \multirow[t]{2}{*}{$\begin{array}{l}\text { Dimensi literasi } \\
\text { sains }\end{array}$} & \multirow[t]{2}{*}{$\begin{array}{l}\text { Realisasi dimensi literasi sains dalan bahan } \\
\text { ajar }\end{array}$} & \multicolumn{2}{|c|}{$\begin{array}{l}\text { Keterpenuhan dimensi literasi } \\
\text { sains dalam bahan ajar }\end{array}$} \\
\hline & & & $\begin{array}{l}\text { Sebelum } \\
\text { Pelatihan }\end{array}$ & $\begin{array}{l}\text { Sesudah } \\
\text { Pelatihan }\end{array}$ \\
\hline 1 & Konteks sains & $\begin{array}{l}\text { Menyajikan bahan bacaan stimulus berupa } \\
\text { konteks sains }\end{array}$ & Tidak ada & Ada \\
\hline 2 & Pengetahuan & $\begin{array}{l}\text { Menyajikan konten sesuai struktur pengetahuan } \\
\text { sains }\end{array}$ & Ada & Ada \\
\hline
\end{tabular}


Yulita \& Amelia: Pelatihan Mengembangkan Bahan Ajar Kimia... (7)

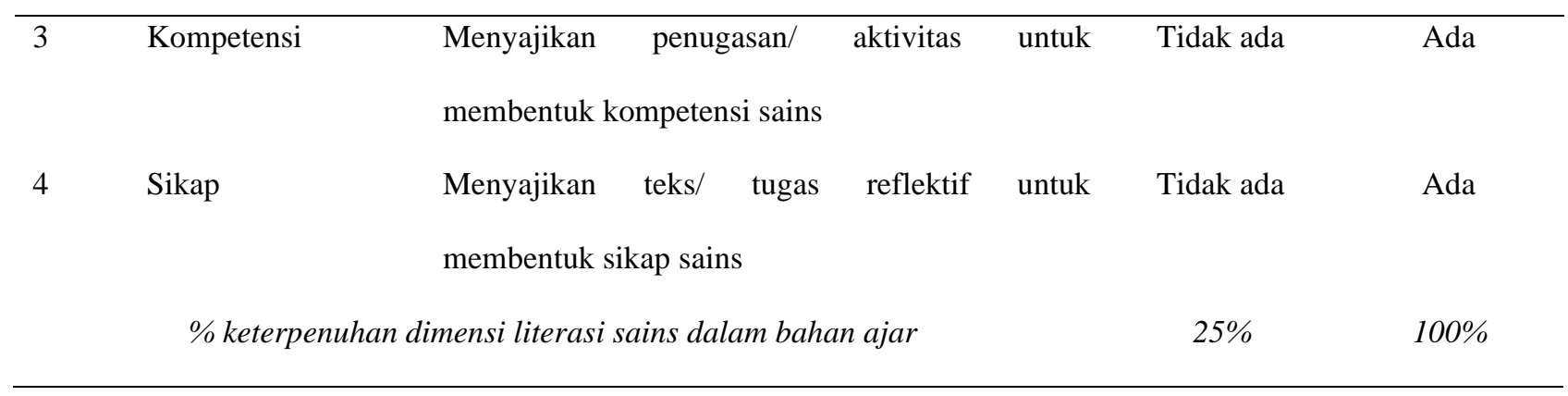

Dari data di atas, dapat diketahui bahwa terjadi peningkatan yang signifikan akan keterpenuhan dimensi literasi sains bahan ajar kimia. Guru sudah mampu menginterpretasikan konteks lingkungan hidup gonggong ke dalam materi kimia tentang asam basa. Dengan kompetensi kondisi air laut berbeda-beda tingkat keasamannya, baik dari posisi (pinggir laut, tengah, permukaan, atau laut dalam), maupun perbedaan daerah (pantai di Kepulauan Riau berbeda dengan pantai di Pulau Jawa).

Pada kegiatan penutup, guru-guru diminta untuk menyampaikan persepsinya mengenai literasi sains dan pentingnya integrasi wawasan kemaritiman dalam pembelajaran kimia. Persepsi guru dirangkum melalui isian angket berbasis google form. Berikut rangkuman isian angket persepsi guru.

Tabel 5

Rangkuman Persepsi Guru

\begin{tabular}{|c|c|c|}
\hline No & Pertanyaan & Persepsi Guru \\
\hline 1 & $\begin{array}{l}\text { Dari kegiatan pelatihan yang sudah } \\
\text { dilakukan, apa yang Ibu pahami } \\
\text { mengenai literasi sains? }\end{array}$ & $\begin{array}{l}\text { Guru 1. Literasi sains merupakan kemampuan kita untuk melek sains } \\
\text { yang ada di sekitar kita, menggunakan atau mengaplikasikan sains yang } \\
\text { kita pelajari dalam memecahkan masalah di kehidupan sehari-hari. } \\
\text { Guru 2. Literasi sains adalah mampu mengidentifikasi pertanyaan, } \\
\text { mendapat pengetahuan baru kemudian menarik kesimpulan dan } \\
\text { membuat keputusan dari apa yg dipelajari terhadap lingkungan } \\
\text { Guru 3. Literasi sains adalah kemampuan untuk memahami keilmuan } \\
\text { sains, menggunakan dan menerapkannya dalam kehidupan sehari-hari. }\end{array}$ \\
\hline 2 & $\begin{array}{l}\text { Berdasarkan pertanyaan nomor } 1 \text {, } \\
\text { tentukan pilihan skala pemahaman } \\
\text { Ibu mengenai literasi sains! }\end{array}$ & $\begin{array}{l}\text { Guru 1. Skala } 5 \text { (Sangat paham) } \\
\text { Guru 2. Skala } 4 \text { (Paham) }\end{array}$ \\
\hline 3 & $\begin{array}{l}\text { Menurut Ibu, seberapa penting } \\
\text { literasi sains diterapkan dalam } \\
\text { pembelajaran? }\end{array}$ & $\begin{array}{l}\text { Guru 1. Skala } 5 \text { (Sangat penting) } \\
\text { Guru 2. Skala } 5 \text { (Sangat penting) } \\
\text { Guru 3. Skala } 4 \text { (Penting) }\end{array}$ \\
\hline
\end{tabular}


JURNAL ANUGERAH, November 2020; Vol 2(2): 51 - 65

4 Berikan penjelasan Ibu mengenai Guru 1. Karena dengan literasi sains siswa dapat mengaplikasi sains jawaban pada pertanyaan nomor 3 yang dipelajari di kelas untuk memecahkan permasalahan dalam di atas! kehidupan sehari-hari. Sehingga pembelajaran menjadi bermakna bagi siswa dalam kehidupannya

Guru 2. Literasi sains sangat penting dalam suatu proses pembelajaran karena dengan literasi mempermudah kita mendapatkan informasi serta jawaban dari proses pembelajaran itu sendiri

Guru 3. Peserta didik memahami apa yang dipelajari serta dapat mengaplikasikannya dalam menyelesaikan berbagai kehidupan seharihari dirumah

5 Menurut Ibu, seberapa penting Guru 1. Skala 5 (Sangat penting)

wawasan kemaritiman/ kelautan Karena negara kita adalah negara maritim, khususnya untuk provinsi diintegrasikan dalam

pembelajaran?

Kepulauan Riau yang memang merupakan daerah kepulauan yang erat

Mohon berikan penjelasan! kaitannya dengan kemaritiman. Jadi pembelajaran yang dilakukan di sekolah sebaiknya dan memang harus sudah mengintegrasikan wawasan kemaritiman supaya apa yang siswa pelajari dapat langsung di aplikasikan dalam kehidupan sehari hari

Guru 2. Skala 5 (Sangat penting)

Karena kita berada di wilayah kepulauan, maka menjadi sangat penting pelajaran berwawasan kemaritiman ini, sehingga kita bisa memperkenalkan biota-biota laut yg ada disekitar kita dan bisa menumbuhkan kesadaran dan sikap untuk menjaga laut supaya biodiversitas nya tetap terjaga dengan baik

Guru 3. Skala 4 (Penting)

Dikarenakan daerah kita dikelilingi laut sebaiknya siswa mengerti potensi alam sekitar dan pentingnya laut bagi kehidupan, maka kemudian siswa bisa bertanggung jawab untuk melestarikan laut

6 Setelah mengikuti pelatihan, Guru 1. Skala 5 (Sangat termotivasi) 


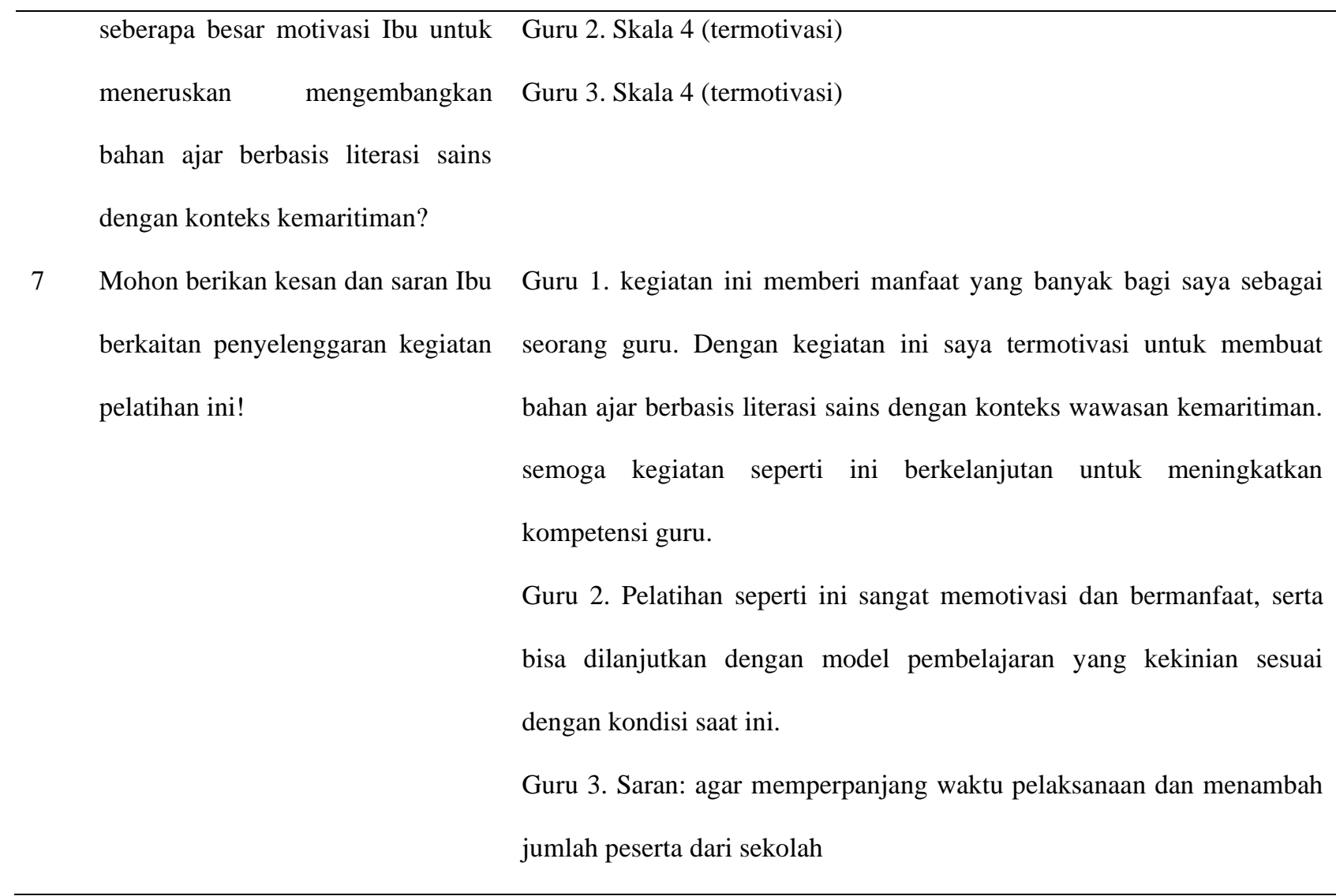

Dari isian angket persepsi guru, dapat diketahui bahwa guru sudah memahami literasi sains, wawasan kemaritiman serta arti penting keduanya dalam pembelajaran. Guru juga menyadari bahwa peserta didik akan memperoleh pembelajaran lebih bermakna jika diintegrasikan literasi sains serta wawasan kemaritiman. Kegiatan yang dilakukan memberikan motivasi kepada guru untuk melanjutkan pembelajaran berbasis literasi sains khususnya dengan mengintegrasikan wawasan kemaritiman.

\section{Kesimpulan}

Kegiatan pengabdian ini berhasil melatih guru mengembangkan bahan ajar kimia yang berbasis literasi sains dengan muatan konteks kemaritiman. Bahan ajar yang dikembangkan adalah bahan ajar kimia materi asam basa dengan mengintegrasikan ke dalam konteks lingkungan hidup gonggong. Di akhir pelatihan didapatkan peningkatan signifikan akan keterpenuhan dimensi literasi sains bahan ajar kimia. Kelebihan dari program pengabdian ini adalah bertambahnya wawasan guru mengenai literasi sains, konteks kemaritiman, dan bertambahnya kemampuan guru dalam mengembangkan bahan ajar berbasis literasi sains.

\section{Saran}

Disarankan untuk program pengabdian masyarakat lebih lanjut agar dapat memberikan durasi yang lebih panjang untuk melakukan pelatihan. Selain itu, program pengabdian dapat diterapkan di beberapa sekolah lainnya di kota Tanjungpinang. Keberlanjutan kegiatan serupa juga sangat penting, sehingga pembelajaran berbasis literasi sains dengan muatan kontekstual terutama isu kemaritiman menjadi konsisten diterapkan di sekolah-sekolah di Tanjungpinang. 


\section{Ucapan Terima Kasih}

Ucapan terima kasih disampaikan kepada DRPM Dikti yang memberikan dana hibah kepada penyelenggara kegiatan Program Kemitraan Masyarakat Stimulus (PKMS) tahun anggaran 2020. Ucapan terima kasih juga disampaikan kepada pihak SMA Negeri 4 Tanjungpinang yang sudah bekerja sama dengan pihak penyelenggaran kegiatan.

\section{Referensi}

Amelia, T., \& Yulita, I. (2019). Desain pembelajaran berbasis literasi sains dan berwawasan kemaritiman sebagai hasil pelatihan di SMAN 4 Tanjungpinang. Jurnal Anugerah, 1(1), 25-31. https://doi.org/10.31629/anugerah.v1i1.1580

Amelia, T., Nevrita, \& Rahmatina, D. (2020). Capaian aspek kompetensi sains siswa SMA dengan pembelajaran model problem-based learning dan cooperative learning tipe STAD. Jurnal Pendidikan Biologi, 9(2), 1 - 9.

Asikin, N., \& Yulita, I. (2019). Scientific literacy-based chemical teaching materials design of chemical solution materials on sea pollution context. Jurnal Penelitian Pendidikan IPA, 5(2), 204. https://doi.org/10.29303/jppipa.v5i2.249

Diana, S., Rachmatulloh, A., \& Rahmawati, E. S. (2015). Profil kemampuan literasi sains siswa SMA berdasarkan instrumen scientific literacy assesments (SLA). Prosiding Seminar Nasional XII Pendidikan Biologi FKIP UNS.

Grant, M., \& Fisher, D. (2011). Teaching science literacy. Retrieved from http://www.ascd.org/publications/educational

OECD. (2020). Science performance (PISA) (indicator). OECD Publishing. Retrieved from https://data.oecd.org/pisa/science-performance-pisa.htm

Riyantini, R. (2017). Pendekatan pdca dalam kegiatan pemantauan pengendalian mutu di lembaga kursus dan pelatihan. Jurnal Ilmiah Visi, 12(2), 143-153. https://doi.org/10.21009/jiv.1202.7

Schleicher, A. (2019). PISA 2018: Insights and interpretations. Retrieved from https://www.oecd.org/pisa/PISA\%202018\%20Insights\%20and\%20Interpretations\%20FINAL\%20PDF .pdf

Schwartz, R. S., Lederman, N. G., \& Crawford, B. A. (2004). Developing views of nature of science in an authentic context: An explicit approach to bridging the gap between nature of science and scientific inquiry. In Science Education. https://doi.org/10.1002/sce.10128

Shwartz, Y., Ben-Zvi, R., \& Hofstein, A. (2006). The use of scientific literacy taxonomy for assessing the development of chemical literacy among high-school students. Chemistry Education Research and Practice. https://doi.org/10.1039/B6RP90011A

Snow, C. E., \& Dibner, K. A. (2016). Science literacy: Concepts, contexts, and consequences. In Science Literacy: Concepts, Contexts, and Consequences. https://doi.org/10.17226/23595

Toharudin, U. et al. (2011). Membangun literasi sains peserta didik. Bandung: Humaniora.

Uno, H. (2008). Perencanaan pembelajaran. Jakarta: Bumi Aksara.

Yulita, I. (2016a). Perspektif saintis terhadap konsep interaksi antarmolekul, printer inkjet dan hubungan keduanya. Prosiding Seminar Nasional Kimia, Jurusan Pendidikan kimia FMIPA UNY

Yulita, I. (2016b). Pre-konsepsi peserta didik terhadap konsep interaksi antarmolekul, printer inkjet dan hubungan keduanya. Jurnal Zarah, 4(1), 19-35.

Yulita, I. (2017). Desain bahan ajar berbasis literasi sains: Hakekat ilmu kimia pada konsteks air laut. In Sinergi Penelitian dan Pembelajaran untuk Mendukung Pengembangan Literasi Kimia pada Era Global. Prosiding Seminar Nasional Kimia UNY 2017.

Yulita, I. (2018). Analisis prekonsepsi siswa terhadap kemampuan menghubungkan konteks air laut dengan 
Yulita \& Amelia: Pelatihan Mengembangkan Bahan Ajar Kimia... (7)

konten hakikat ilmu kimia kelas $\mathrm{X}$ SMA. Jurnal pendidikan sains (JPS). https://doi.org/10.26714/jps.6.1.2018.64-72 
JURNAL ANUGERAH, November 2020; Vol 2(2): 51 - 65 e-ISSN 2715-8179 